\title{
狭路走行支援システム使用時における 高齢ドライバーの運転特性
}

○佐藤稔久（慶應義塾大学大学院），川嶋弘尚，大門 樹（慶應義熟大学）

A Study on Elder Drivers' Characteristics When Using Nar row Road Driving Assistance System Toshihisa SATO (Graduate School of Keio University), Hironao KAWASHIMA, Tatsuru DAIMON (Keio University)

\section{1.はじめに}

近年，ITS (高度道路交通システム) の取り 組みとして，予防安全や利便性の観点から視覚 情報や聴覚情報を事前に提供することにより ドライバーの運転支援を行うシステムが開発 されている. 高齢の運転免許保有者の増加に従 い，高齢ドライバーの運転中における事故が増 大しているが，このITS 技術により大幅な事故 軽減効果が期待されている[1]. 今後, このよう に多種多様な情報提供が行われると想定され るが，加齢に伴う心身機能の低下が ITS アプリ ケーション使用時の高齢ドライバー特性にど のような影響を与えるのかについては明らか になっていない。

本研究では，今後実用化されるITSアプリケ ーションの1つである狭路走行支援システムを 取り上げる。狭路走行支援システムは, 市街地 内の細い道路で電柱や駐車車両のような障害 物の位置や距離情報をドライバーへ呈示する ことにより，狭路走行時の負担を軽減するシス テムである。ここでは，支援システム使用時の 高齢ドライバー特性を若年ドライバー特性と 比較・検討し，狭路を安全にスムーズに通過す るための視覚情報提供方法について検討した。

\section{2. 実験}

実験では，図1に示したドライビングシミュ レータを使用した。実験コースは市街地データ ベース上の細街路に駐車車両と電柱を配置し て構築した。

狭路走行時のドライバー特性に関する先行 実験の結果より，狭路を安全に通過するための 推奖経路を呈示寸ることが狭路走行時の負担 軽減に有効であるという知見が得られた ${ }^{[2]}$. 本 研究では, 次のように, 推奨経路を呈示するシ ステムと，支援システム使用時のドライバー情 報処理モデルの検討からここで提案するステ アリング操作情報を呈示するシステムを用い て実験を行った。

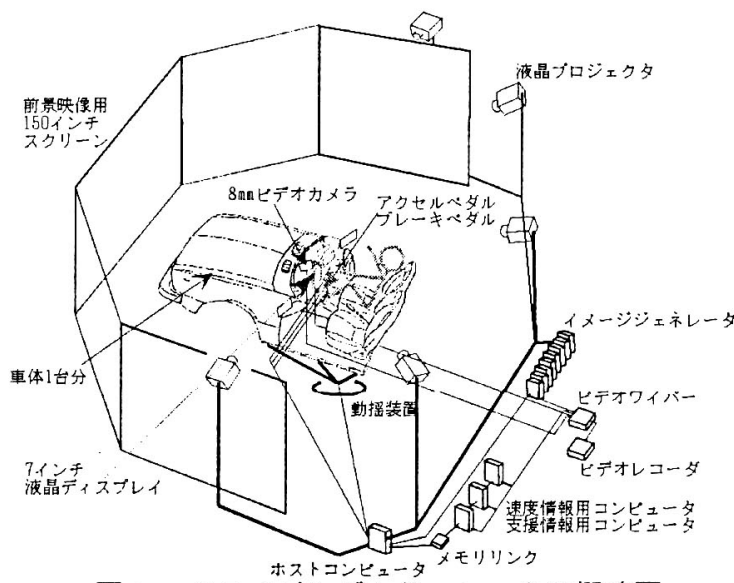

図 1.ドライビングシミュレータの概略図

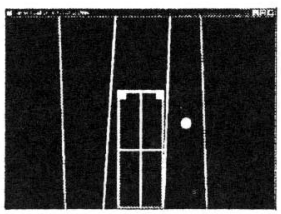

(左：通常時 右：障害物接近時)

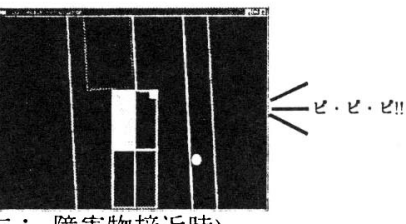

ダッシュボード上に設置された車載ディスプレイ に推奖経路と自車, 障害物の位置関係を表示。障害 物接近時は, 自車の衝突予想部分が黄色く点滅し, 同時にビープ音を呈示した。

図 2. 車載ディスプレイ情報

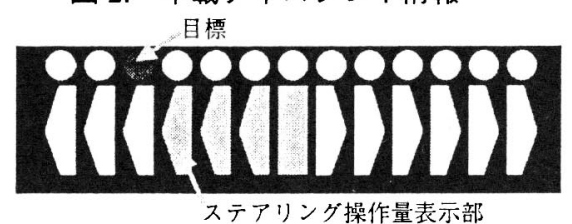

ステアリング操作量表示部がステアリング操作に 連動して変化し，目標の位置まで操作するというも の.インストルメントパネル奥に設置した HUDに 表示. 推奖経路通りに走行するためのスデアリング 操作量を呈示した。

図 3. ステアリング操作情報 インターフェース 1：車載ディスプレイ情報 (図 2)を表示

インターフェース 2 ：車載ディスプレイ情報 に加えてステアリング操作情報(図 3)を表示

被験者は, 高齢被験者 6 名(平均年齢 66.3 歳 
$\mathrm{SD}: 1.6$ ), 若年被験者 6 名(平均年齢 23.5 歳 SD: 1.5)で，普段通りに運転を行い，絶対に障害物 に衝突しないように指示された。またイインタ ーフェースの表示内容に関して実験前に十分 に理解してもらった。実験走行は情報提供なし の場合とインターフェース 1, インターフェー ス 2 を使用した場合の計 3 回行った。

\section{3. 結果および検討}

表 1. 障害物に衝突した被験者数 (人数)

\begin{tabular}{|c|c|c|}
\hline & 高齢 & 若年 \\
\hline \hline 情報提供なし & 1 & 2 \\
\hline $\begin{array}{c}\text { インターフェース1 } \\
\text { (車載ディスプレイ情報) }\end{array}$ & 3 & 0 \\
\hline $\begin{array}{c}\text { インターフェース2 } \\
\text { (車載ディスプレイ情報 } \\
\text { +ステアリング操作情報) }\end{array}$ & 0 & 0 \\
\hline
\end{tabular}

障害物に衝突した被験者数を表 1 に示す. 高 齢被験者は，インターフェース 1 使用時の方が 情報提供なしの場合よりも障害物に衝突した 被験者数は多い結果となった。若年被験者は, 情報提供なしの場合，障害物に衝突した被験者 は 2 名いたが，インターフェース 1 使用時は 0 名であった。このことから，インターフェース 1 は高齢被験者にとって運転の妨げとなったと 考えられる.インターフェース 2 使用時は, 高 齢被験者, 若年被験者とも衝突者数は 0 名であ り, 走行軌跡の結果より, 推奖経路通りに走行 できスムーズに狭路を通過する傾向が見られ た。

図 4 に支援情報に対する 1 回あたりの平均注 視時間の結果を示す.

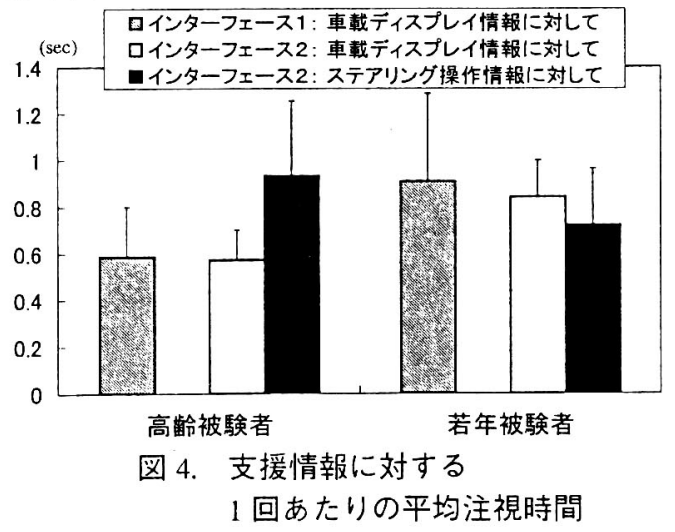

車載ディスプレイ情報に対する 1 回あたりの 平均注視時間は，インターフェース 1, 2 使用 時とも高齢被験者は若年被験者に比べて短か った。一方，ステアリング操作情報に対する 1 回あたりの平均注視時間は，高齢被験者の方が
若年被験者よりも長くなった，若年被験者は車 載ディスプレイ情報に対する注視時間の方が ステアリング操作情報に対する注視時間より も長いという結果となったが, 高齢被験者はそ の逆の結果となった。

一般的に，加齢による心身機能の衰えとして， 高齢者は周辺視野が狭い, 認知・判断に要する 時間が長いということがいわれている ${ }^{[1][3]}$. 走 行軌跡, 注視行動の結果より, 車載ディスプレ イ情報はその情報量が多いことや前方からの 注視点の移動距離が長いため，高齢被験者は支 援システムとして利用できなかったと考えら れる。一方，ステアリング操作情報は，目標に ステアリング操作量表示部を合わせるという 単純な情報形式であること，また前方からの注 視点の移動距離が短いことから, 高齢被験者は, インターフェース 2 の方は支援システムとして 利用できたと思われる。以上の結果から，高齢 被験者はインターフェース 2 を使用することで, 安全にスムーズに狭路を走行することが出来 たと考えられる. 実際, 狭路走行時における精 神的作業負担の主観的評価や狭路通過時の指 尖脈派を分析した結果より，高齢被験者にとっ て，情報提供なしやインターフェース 1 使用時 よりもインターフェース 2 使用時の方が, 狭路 走行時の精神的作業負担が小さいという結果 が得られた。

\section{4. まとめ}

本研究により以下の結果が得られた。

1) 高齢ドライバーは, 若年ドライバーに比べて 周辺視野が狭いことや情報処理能力が低下し ていることから，車載ディスプレイ情報のみで は支援システムとして利用することが出来な かった。

2）車載ディスプレイ情報に加えてステアリン グ操作情報を呈示することは，高齡ドライバー にとっても若年ドライバーにとっても，安全に 狭路を走行することに，また，狭路走行時の精 神的作業負担の軽減に効果が見られた。

\section{参考文献}

[1] 片山 硬：高齢者の運転特性, 自動車研究, Vol.23, No.1, 49 55, 2001

[2] 佐藤稔久, 大門 樹ほか：ドライバの認知 過程を考慮した狭路走行支援システムに関す る研究, 自動車技術会 学術講演会前刷集, No.107-99, 9 12, 1999

[3] 小谷津孝明, 星 薰: 認知心理学, 157 171, 放送大学教育振興会，東京，1994 